NBER WORKING PAPER SERIES

\title{
ELECTORAL ACCOUNTABILITY AND CORRUPTION: EVIDENCE FROM THE AUDITS OF LOCAL GOVERNMENTS
}

\author{
Claudio Ferraz \\ Frederico Finan \\ Working Paper 14937 \\ http://www.nber.org/papers/w14937
NATIONAL BUREAU OF ECONOMIC RESEARCH
1050 Massachusetts Avenue
Cambridge, MA 02138
April 2009

We are grateful to Sandra Black, Allan Drazen, Alain de Janvry, Seema Jayachandran, Joe Hotz, Philip Keefer, Maurizio Mazzocco, Ted Miguel, Enrico Moretti, Sarah Reber, James Robinson, Gerard Roland, Elisabeth Sadoulet, Helena Svaleryd, Duncan Thomas and to conference and seminar participants at CERGE-EI, Dartmouth College, EPGE-FGV, IADB, IPEA-Rio, LACEA-Political Economy Network, MIT, NBER, NEUDCBrown, Penn State University, PUC-Rio, Stanford GSB, UC-Berkeley, UCLA, University of Maryland, Wharton Business School, World Bank, and Yale University. We also thank the staff at the Controladoria Geral da União (CGU) for information about the details of the anti-corruption program and Paula Aniceto, Leonardo Costa and Tássia Cruz for excellent research assistance. Ferraz gratefully acknowledges financial support from CAPES-Brazil. The views expressed herein are those of the author(s) and do not necessarily reflect the views of the National Bureau of Economic Research.

NBER working papers are circulated for discussion and comment purposes. They have not been peerreviewed or been subject to the review by the NBER Board of Directors that accompanies official NBER publications.

(C) 2009 by Claudio Ferraz and Frederico Finan. All rights reserved. Short sections of text, not to exceed two paragraphs, may be quoted without explicit permission provided that full credit, including $\odot$ notice, is given to the source. 
Electoral Accountability and Corruption: Evidence from the Audits of Local Governments

Claudio Ferraz and Frederico Finan

NBER Working Paper No. 14937

April 2009

JEL No. D72,D78,H41,O17

\begin{abstract}
$\underline{\text { ABSTRACT }}$
Political institutions can affect corruption. We use audit reports from an anti-corruption program in Brazil to construct new measures of political corruption in local governments and test whether electoral accountability affects the corruption practices of incumbent politicians. We find significantly less corruption in municipalities where mayors can get reelected. Mayors with re-election incentives misappropriate 27 percent fewer resources than mayors without re-election incentives. These effects are more pronounced among municipalities with less access to information and where the likelihood of judicial punishment is lower. Overall our findings suggest that electoral rules that enhance political accountability play a crucial role in constraining politician's corrupt behavior.
\end{abstract}

\author{
Claudio Ferraz \\ Department of Economics \\ PUC-Rio \\ Rio de Janeiro, RJ, 22453-900 \\ Brazil \\ cferraz@econ.puc-rio.br \\ Frederico Finan \\ Department of Economics \\ UCLA \\ Box 951477 \\ Los Angeles, CA 90095-1477 \\ and NBER \\ ffinan@econ.ucla.edu
}




\section{Introduction}

The abuse of entrusted power by politicians through rent-seeking and corruption is a threat to many modern democracies. Developing countries, in particular, provide seemingly endless examples of political elites diverting funds intended for basic public services such as health, schools, and roads for private gains. ${ }^{1}$ While the pervasive effects of corruption on economic development have been well documented, the root causes are poorly understood. ${ }^{2}$

Variation in electoral systems is believed to explain a significant portion of the differences in corruption practices across countries. Because voters can oust corrupt politicians from office, electoral rules that enhance political accountability should constrain the behavior of corrupt politicians. ${ }^{3}$ However, while there are convincing theoretical arguments for why political institutions affect corruption (see for example Myerson (1993) and Persson, Roland, and Tabellini (1997)), the empirical evidence identifying the specific electoral structures that discipline politicians' behavior suffers from at least two important shortcomings. First, most of these studies are based on indices that measure perceptions rather than actual political corruption. Second, many have relied primarily on cross-country analysis, where the inability to account for the full set of institutional arrangements that determine corruption has made results difficult to interpret.

In this paper, we use audit reports from an anti-corruption program in Brazil to construct new measures of corruption in local governments. We estimate the share of total federal resources transferred to municipalities that is associated with fraud in procurements, diversion of funds, and over-invoicing for goods and services. By measuring corruption using detailed audit reports, we are able to separate funds diverted from simple irregularities in bureaucratic procedures. Moreover, local governments in Brazil provide an ideal institutional setting to examine how local electoral accountability affects corruption. Municipal governments are responsible for the provision of important public services receiving large sums of resources from the federal government. Thus, it is not surprising that corruption at the municipal level, as in many other countries, has become an overarching concern (Rose-Ackerman 1999). Based on our estimates, corruption is responsible for losses of approximately $\mathrm{R} \$ 1.5$ Billion (US $\$ 554$ Million) for local governments. ${ }^{4}$

With estimates for corruption at the municipal level, we compare mayors serving in a first term to mayors in their second term (who face a term-limit) to identify the effects of re-election

\footnotetext{
${ }^{1}$ See for example Di Tella and Schargrodsky (2003), Olken (2007), Reinikka and Svensson (2004)

${ }^{2}$ See Knack and Keefer (1995), Mauro (1995), Bertrand et al. (2007) for studies examining the impacts of corruption.

${ }^{3}$ Adsera, Boix, and Payne (2003), Kunicová and Rose-Ackerman (2005), Lederman, Loayza, and Soares (2005), Persson, Tabellini, and Trebbi (2003) provide cross-country evidence of the association between electoral rules and perceptions of corruption.

${ }^{4}$ We compute this number by using our estimate of misappropriation of 6 percent and applying it to R $\$ 24.8$ Billion transferred to 5118 municipalities with population less than 450,000 persons in 2002. See Veja (2004) for examples of widespread local corruption.
} 
incentives. Our identification uses variation only from municipalities audited at the same time and in the same state, while controlling for a full set of mayor and municipal characteristics. Also, by estimating the effects of re-election incentives on political corruption at a sub-national level, we keep constant the macro-level institutions, both formal and informal, whose differences plague most cross-country analysis.

Consistent with a simple political agency model, we find that mayors with re-election incentives are significantly less corrupt than mayors without re-election incentives. In municipalities where mayors are in their first term, the share of resources misappropriated is, on average, 27 percent lower than in municipalities with second-term mayors. The results are robust to not only various specifications and estimation strategies, but also to alternative measures of corruption. Considering that municipalities receive, on average, $\mathrm{R} \$ 5,459,209$ (US\$2,017,259) of federal transfers, lame-duck mayors misappropriate approximately $\mathrm{R} \$ 148,000$ (US\$54,688) more than first-term mayors. Assuming that in the absence of re-election incentives, first-term mayors would behave as second-term mayors, re-election incentives are responsible for inducing a reduction in resources misappropriated in the order of $\mathrm{R} \$ 433$ million (US\$160 million). This is almost half of what the federal government spent on the Bolsa Escola conditional cash transfer program for all municipalities in Brazil during 2002. We also find that the effects of re-election incentives vary considerably according to differences in the local institutional settings that govern either the provision of information or the potential punishment corrupt politicians might suffer. For instance, among municipalities with the presence of local media or local public prosecutors, we find little differential effect between first and second-term mayors. Conversely, for the municipalities without local media, re-election incentives reduce political corruption by 9 percentage points. The effects of re-election incentives are also more pronounced in municipalities where the elections were competitive suggesting that first term mayors with an electoral advantage can afford to be more corrupt.

We also provide several robustness tests that suggest that our findings are not driven by unobserved differences in municipal characteristics, political ability or learning between first and second term mayors. First, using a regression discontinuity analysis, we compare municipalities where incumbent mayors barely won reelection in 2000 (and thus served as a second-term mayor from 2001-2004) to municipalities where the incumbent barely lost the election and thus was replaced by a new mayor (who then served as a first term between 2001-2004). This allow us to control for many unobserved characteristics of the municipality that determine both re-election and corruption levels. Second, we also compare second-term mayors with the set of first-term mayors who are re-elected in the subsequent election, and are thus potentially as politically able as second-term mayors. Third, we exploit the fact that some second-term mayors still have career concerns and seek higher level political offices. Although in their final term, these mayors should behave similarly to mayors who still have re-election incentives. Finally, we compare mayors 
with similar political experience to account for any potential differences in corruption between first and second-term mayors that might reflect learning-by-doing from political office.

The importance of elections as a disciplining device is well recognized in the literature. This paper, by using objective measure of corruption and exploiting within country variation in reelection incentives, overcomes many of the literature's previous limitations to provide, to the best of our knowledge, the first test of how electoral accountability affects political corruption. More broadly, our findings contribute to a growing literature that test the traditional political economy agency models of Barro (1970), Ferejohn (1986) and Banks and Sundaram (1993). ${ }^{5}$ These models predict that incumbent politicians will refrain from maximum rent-extraction in their first electoral term in order to get re-elected and enjoy future rents. ${ }^{6}$ Our findings also complement Ferraz and Finan (2008) who show that voters punish corrupt politicians when information about corruption practices are publicized. Together, these results suggest that electoral accountability act as a powerful mechanism to align politicians' actions with voters' preferences.

The remainder of the paper is organized as follows. Section 2 presents a theoretical framework that links corruption to re-election incentives. It is within this context that we interpret our empirical results. Section 3 provides some basic background information on corruption in Brazil, and section 4 describes the data and how we construct our measures of corruption. Our empirical strategy is discussed in section 5 . The results are presented in section 6 , followed by a discussion of the findings in section 7 . Section 8 concludes the paper.

\section{Theoretical Framework}

In this section, we present a simple model to help interpret our empirical findings. We utilize the political agency framework of Besley (2006), whereby voters decide whether to re-elect an incumbent, but are unable to observe either his type or actions. ${ }^{7}$ In a world of corrupt and non-corrupt politicians, a corrupt mayor who faces the possibility of re-election can exploit this information asymmetry to increase re-election chances by refraining from rent-seeking and behaving as a non-corrupt mayor. Given these re-election incentives, the model predicts that mayors who face re-election incentives will on average be less corrupt than mayors who do not. ${ }^{8}$

\footnotetext{
${ }^{5}$ Besley and Case (1995) show that re-election incentives affect the fiscal policy of U.S. governors, and List and Sturm (2006) provide evidence that term limits even influence secondary policies, such as environmental policy.

${ }^{6}$ See Persson and Tabellini (2000) and Besley (2006) for excellent reviews of political agency models.

${ }^{7}$ Besley (2006) is an adaptation the political agency model of Besley and Smart (2007) and Banks and Sundaram (1993), which extended the earlier work of Barro (1970), Ferejohn (1986), Persson, Roland, and Tabellini (1997).

${ }^{8}$ Campante, Chor, and Do (2006) presents an alternative model where corruption depends on politician's stability. Politicians facing more uncertainty about re-election (a shorter horizon) will extract more rents from power.
} 


\section{Basic Model}

Consider a two-period model with two types of politicians: a non-corrupt politician $n c$ and a corrupt politician $c$. Let $\pi$ denote the proportion of non-corrupt politicians in the pool of potential candidates. In each period, the elected politician sets a state-dependent policy $e_{t}\left(s_{t}, i\right)$, where $i \in\{c, n c\}$ is the type of politician and $s_{t} \in\{0,1\}$ is the state of the world at time $t$. Each state occurs with equal probability and is only observed by the incumbent politician.

Given the choice of policy, voters receive a payoff of $V$ if $e_{t}=s_{t}$ and zero otherwise. ${ }^{9}$ Noncorrupt politicians set policy to maximize voters' objectives, whereas corrupt politicians receive a private benefit $r_{t}$ for setting $e_{t} \neq s_{t}$. The private benefit is randomly drawn each period from a distribution $G(r)$ with mean $\mu$ and finite support $[0, R]$. The model assumes that $R>\delta(\mu+E)$ where $\delta$ is a common discount factor less than one and $E$ denotes ego-rents that politicians enjoy from holding office.

The timing of this game is as follows. A politician is elected at the beginning of each period, after which nature reveals to the incumbent the state of the world. If newly elected, nature also reveals his type. Corrupt incumbents then receive a random draw from the distribution $G(r)$ of private benefits. After policy is set, voters observe their payoffs and then decide whether or not to re-elect the incumbent or select a challenger who has been drawn at random from the pool of potential politicians. After elections are held, the corrupt politicians receive another independent draw $r_{2}$ from the distribution $G(r)$. Period 2 actions then follow and payoffs are realized.

The perfect Bayesian Nash equilibrium of this game requires that each politician behaves optimally in each period, given the decision rule of the voters. Because the game ends in period 2 , absent re-election incentives, each politician sets his preferred policy. Non-corrupt incumbents will set $e_{2}(s, n c)=s_{2}$, and corrupt incumbents will set $e_{2}(s, c)=1-s_{2}$ to receive $r_{2}$. Since voters are better off with non-corrupt incumbents in period 2 , they maximize the likelihood that a noncorrupt politician is elected to the second period.

The equilibrium in period 1 is much more intriguing. While non-corrupt incumbents will still behave in accordance with voters' objectives, corrupt politicians face a tradeoff. A corrupt politician can extract rents $r_{1}$ in period 1 and forgo re-election, or alternatively behave as a non-corrupt politician to guarantee re-election and reap the benefits of a second term. ${ }^{10}$ Given this tradeoff, the probability that a corrupt politician provide voters with a positive payoff in period 1 is simply $\operatorname{Pr}\left(r_{1} \leq \delta(\mu+E)\right)$ : the probability that $r_{1}$ is less than the present value of expected future benefits from holding office in period 2. Based on the distributional assumptions of $r_{1}$, this probability, which we denote as $\lambda$, is equal to $G(\delta(\mu+E))$.

Besley (2006) shows that in equilibrium non-corrupt politicians always set $e_{t}=s_{t}$. Corrupt

\footnotetext{
${ }^{9}$ The payoffs could be related instead to the levels of public good provision.

${ }^{10}$ Voters observing $V$ will re-elect the incumbent politicians. To see this, note that the probability that a
} 
politicians choose $e_{2}=\left(1-s_{2}\right)$ in period 2 , and $e_{1}=s_{1}$ in period 1 , provided they earn sufficiently small rents. All politicians who choose $e_{1}=s_{1}$ will get re-elected. In equilibrium, if the ratio of disciplined politicians to non-disciplined politicians is larger than the share of non-corrupt types, i.e. $\frac{\lambda}{1-\lambda} \geq \pi$, then rent extraction will on average be higher in the second period than in the first period, that is, ${ }^{11}$

$$
(1-\pi)(1-\lambda) \int_{r_{1} \geq \delta(\mu+E)}^{R} r d G(r) \leq(1-\pi) \lambda \int_{0}^{R} r d G(r)+(1-\pi)(1-\lambda)(1-\pi) \int_{0}^{R} r d G(r) .
$$

The intuition for this result is simple. When faced with the possibility of re-election, corrupt politicians have the incentive to reduce rent extraction and provide more public goods. Assuming the disciplining effect $\lambda$ is large enough, rents will on average be higher in the second period, relative to the first period. This is the main testable prediction that we take to the data.

\section{$3 \quad$ Institutional Background}

Several institutional features of Brazil facilitate the test of whether political incentives affect corruption levels. First, re-election incentives were introduced in 1997 through a constitutional amendment that enabled mayors to run for a second consecutive term. This amendment allows us to compare the corruption levels between municipalities where mayors are in their first term to those where mayors are in their second term. Second, in 2003 the Controladoria Geral da União (CGU) introduced an ambitious anti-corruption program that audits municipalities for their use of federal funds. These audit reports provide objective measures of corruption at the municipal level.

Moreover, municipal corruption has become an overarching concern for Brazil. ${ }^{12}$ After the constitution of 1988, municipal governments became responsible for a substantial share of the provision of public goods and services, particularly in the areas of education and health. With the devolution of public service delivery to local governments, the federal government transferred politician is non-corrupt conditional on observing $V$ is:

$$
\begin{aligned}
\operatorname{Pr}(i=N C \mid V) & =\frac{\operatorname{Pr}(V \mid i=N C) \operatorname{Pr}(i=N C)}{\operatorname{Pr}(V)} \\
& =\frac{\operatorname{Pr}(V \mid i=N C) \operatorname{Pr}(i=N C)}{\operatorname{Pr}(i=N C)+\operatorname{Pr}(i=C) \operatorname{Pr}\left(r_{1} \leq \delta(\mu+E)\right)} \\
& =\frac{\pi}{\pi+(1-\pi) \operatorname{Pr}\left(r_{1} \leq \delta(\mu+E)\right)} \geq \pi
\end{aligned}
$$

\footnotetext{
${ }^{11}$ The condition that $\frac{\lambda}{1-\lambda} \geq \pi$ is sufficient but not necessary for rents to be higher in the second period. Rents are higher in the second period if the following inequality holds: $\pi \int_{r_{1} \geq \delta(\mu+E)}^{R} r d G(r)<\frac{\lambda}{1-\lambda} \int_{r_{1} \geq \delta(\mu+E)}^{R} r d G(r)+$ $(\lambda+(1-\lambda)(1-\pi)) \int_{0}^{r_{1} \leq \delta(\mu+E)} r d G(r)$.

${ }^{12}$ For a detailed article on municipal corruption see VEJA (2004).
} 
large amounts of resources to municipalities. Currently, the 5,560 Brazilian municipalities receive on average $\$ 35$ billion per year from the federal government, which represents approximately 15 percent of federal government's revenue. ${ }^{13}$ This influx of federal funds has substantially increased the potential for local capture.

\subsection{Corruption Schemes in Brazil's Municipalities}

Municipal-level corruption takes on a variety of other forms. Frauds in procurement processes, diversion of funds, and over-invoicing for goods and services are among the most common ways local politicians find to appropriate resources. ${ }^{14}$ Other common irregularities include incomplete public works (paid for but unfinished); the use of fake receipts ("notas frias") and phantom firms (a firm that only exists on paper).

Some examples are useful to illustrate these corruption technologies. A common scheme used to deviate public resources in the municipalities of El Dorado dos Carajés and Porto Seguro, for example, include the creation of phantom firms, simulation of the call for bids, and kickbacks to government officials. ${ }^{15}$ In other contracts, although existing firms did win the bid, none of them were even aware that they had participated in the bidding process. The local administration used the names of these firms in fake receipts to appropriate resources for public goods that were never provided.

Another irregular practice, common in several municipalities, is a non-competitive procurement process. While the Brazilian law requires a competitive bidding process with at least three participants for any project in excess of $\$ 30,000$ per year, the municipality of Itapetinga in the state of Bahia, for example, highlights one of the many ways local politicians have manipulated the public procurement process. In 2002 and 2003, the federal government transferred to Itapetinga $\$ 110,000$ for the purchase of school lunches. In 12 out of the 16 calls for bids, only one bid was ever supplied. It was later discovered that each call for bids was posted only one hour prior to its deadline, and not surprisingly only a firm owned by the mayor's brother posted within the time limit. This same scheme was uncovered for other social programs in the areas of education and health.

Another common form of corruption is for mayors to divert funds intended for education and health projects towards the purchase of cars, fuel, apartments, or payment of their friends' salaries. In some cases, the mayor himself is a direct beneficiary. For example, in Paranhos, Mato Grosso do Sul, $\$ 69,838$ was paid to implement a rural electrification project. As it turns out, one of the farms benefitted by the project was owned by the mayor.

\footnotetext{
${ }^{13}$ For comparison, fiscal decentralization in the world is on average 6 percent, while in other similar developing countries it is only 3 percent.

${ }^{14}$ For a description of municipal corruption schemes in Brazil see Trevisan et al. (2004).

${ }^{15}$ These descriptions are based on several CGU reports and press releases available at: www.presidencia.gov.br/cgu.
} 


\subsection{Brazil's Anti-Corruption Program: an Overview}

In May 2003 the government of Luiz Inácio Lula da Silva started an unprecedented anticorruption program based on the random auditing of municipal government's expenditures. The program, which is implemented through the Controladoria Geral da União (CGU), aims to discourage misuse of public funds among public administrators and fostering civil society participation in the control of public expenditures.

The program started with the audit of 26 randomly selected municipalities, one in each state of Brazil. It has since expanded to auditing 50 and later 60 municipalities per lottery, from a sample of all Brazilian municipalities with less than 450,000 inhabitants. ${ }^{16}$ The lotteries, which are held on a monthly basis at the Caixa Econômica Federal in Brasilia, are drawn in conjunction with the national lotteries. To assure a fair and transparent process, representatives of the press, political parties, and members of the civil society are all invited witness the lottery.

Once a municipality is chosen, the CGU gathers information on all federal funds transfers to the municipal government from 2001 onwards. Approximately 10 to 15 CGU auditors are then sent to the municipality to examine accounts and documents, to inspect for the existence and quality of public work construction, and delivery of public services. Auditors also meet members of the local community, as well as municipal councils in order to get direct complaints about any malfeasance. ${ }^{17}$ After approximately one week of inspections, a detailed report describing all the irregularities found is submitted to the central CGU office in Brasilia. The reports are then sent to the Tribunal de Contas da União (TCU), to public prosecutors and to the legislative branch of the municipality. For each municipality audited, a summary of the main findings is posted on the internet and disclosed to media sources. It is from these reports that we construct an objective measure of corruption.

\section{Measuring Corruption}

In this section, we describe how our measures of corruption are computed and present summary statistics of the corruption measures and municipal characteristics.

\subsection{Measuring Corruption using Audit Reports}

As with any illegal activity, obtaining data on corruption is a difficult task. Several empirical studies that focus on illegal behavior have used indirect evidence to analyze its determinants and consequences (see for example Duggan and Levitt (2002); Fisman (2002); Fisman and Wei

\footnotetext{
${ }^{16}$ This excludes approximately 8 percent of Brazil's 5500 municipalities, comprising mostly of the state capitals and coastal cities.

${ }^{17}$ These auditors are hired based on a public examination, and prior to visiting the municipality receive extensive training on the specificities of the sampled municipality. Also, there is a supervisor for each team of auditors.
} 
(2004), Bandiera, Prat, and Valletti (2007)). However, a small, but growing body of literature has tried to assess corruption more directly focusing on two forms: bribery of public officials and the theft of public resources (Svensson (2003); Di Tella and Schargrodsky (2003); Reinikka and Svensson (2004); Olken (2007)).

Our approach, although related to the studies cited above, uses a new methodology made possible by the availability of audit reports from Brazil's anti-corruption program. Contained in each report is the total amount of federal funds audited for the current administration, as well as, an itemized list describing each irregularity and in most cases the amount of funds involved. Audit reports were available in the beginning of 2004 for the 496 municipalities randomly selected across the first 11 lotteries of the anti-corruption program. ${ }^{18}$ We read each report classifying the irregularities found by auditors into corruption indicators and estimate the amount of public resources misappropriated for each irregularity.

Based on our readings of the reports, we codified the irregularities listed into several categories of corruption. ${ }^{19}$ For the purpose of coding, we define political corruption to be any irregularity associated with fraud in procurements, diversion of public funds, and over-invoicing. Specifically, we define a procurement to be irregular if: i) a required procurement was not executed; ii) the minimum number of bids was not attained; iii) there was evidence of fraud in the procurement process (e.g. use of bids from non-existing firms). We categorize diversion of public funds as any expenditure without proof of purchase or provision and/or direct evidence of diversion provided by the CGU. Finally, we define over-invoicing as any evidence that public goods and services were bought for a value above the market price.

These practices have not only been shown to be the most common ways in which local politicians appropriate resources, but in many instances they are not necessarily mutually exclusive (see Trevisan et al. (2004)). In effect, over-invoicing and illegal procurement practices often serve as complementary vehicles for funds diversion. To give a better sense of the irregularities found and the procedure used to code corruption, we present in the appendix some specific examples from the audit reports.

Based on the coding of the reports, we define as our principal measure of corruption the total amount of resources related to corrupt activities, expressed as a share of the total amount of resources audited. While this is our preferred measure, we also report two additional indicators of corruption: the number of irregularities related to corruption and the share of service items associated with corruption, which simply divides the number of irregularities related to corruption by the number of service items audited.

\footnotetext{
${ }^{18}$ Only 26 municipalities were selected in the first lottery. From lottery two to lottery nine, 50 municipalities were chosen in each. Starting on the tenth lottery in May of 2004, the CGU increased the number of municipalities sampled to 60 .

${ }^{19} \mathrm{We}$ also used two independent research assistants to code the reports in order to provide a check on our coding.
} 
There are at least two reasons why we calculate these additional measures. First, although highly correlated with our main measure, these other indicators help to distinguish whether second-term mayors also engage in more corrupt transactions. Second, in coding the amount of resource deviated or involved in an illegal procurement, a dollar amount was not available in all of the irregularities reported. ${ }^{20}$ While coding these cases as zero underestimates the amount of corruption, this could create a bias for testing re-election incentives if the cases occurred disproportionately for first-term mayors. ${ }^{21}$ By using additional measures we include these irregularities and thus avoid the potential bias.

\subsection{Summary Statistics on Corruption and Government Irregulari- ties}

Summary statistics for each one of the three corruption categories and the overall corruption indicator are displayed in Table 1. As seen in row 1, 57 percent of the municipalities have performed an illegal procurement practice, and 54 percent of the municipalities have diverted some type of funds. Over-invoicing is found much less frequently, occurring in only 7 percent of our sample. After combining these indicators, we see that 78 percent of the municipalities have had at least one incidence of corruption. Moreover, those administrations that commit an act of corruption average around 2.47 corrupt violations, which is 7 percent of the service items audited. The average amount of resources diverted is $\mathrm{R} \$ 125,000$ (US\$46,297) per violation which represents 8.7 percent of the total amount audited. ${ }^{22}$

To get a sense for how re-election incentive may affect these various irregularities, Table 2 compares these indicators between municipalities with mayors in their first-term to those with mayors in their second-term. In the first set of columns, the share of audited resources found to be associated with corruption is 1.9 percentage points higher for second-term mayor, and significant at 95 percent level of confidence. Second-term mayors are also more corrupt in each of the 3 categories of corruption (diversion of funds, illegal procurement practices, and overinvoicing), but it is the difference in illegal procurement that accounts for much of the difference in the aggregate measure. On average, the share of resources that are diverted illegally in the procurement of public works is 1.7 percentage points higher among second-term mayors than first-term mayors (standard error is 0.7).

When corruption is measured as either the incidence of irregularities or the share of service

\footnotetext{
${ }^{20}$ Approximately 89 percent of the incidences of illegal procurement practices and funds diversion have a value.

${ }^{21}$ If anything we are underestimating the effect of re-election incentives on the share of total resources associated with corruption, because the proportion of these irregularities is 4 percentage points higher for second-term mayors, although not statistically significant.

${ }^{22}$ In general, we see that a large number of irregularities occur in the areas of education and health, sectors that were decentralized during of the late 1980s. See Ferraz and Finan (2007) for a more detailed account of the distribution of corruption practices across types and sectors.
} 
items, columns 4-9 of Table 2 provide further evidence in support of the theoretical predictions. Compared to first-term mayors, second-term mayors commit 0.11 and 0.23 more irregularities in the diversion of funds and illegal procurement practices respectively, which represent 0.4 and 0.7 percentage points differences in the share of services items audited.

\subsection{Data on Municipal Characteristics}

The other data sources used in the analysis were obtained from the Brazilian Institute of Geography and Statistics (Instituto Brasileiro de Geografia e Estatística (IBGE)), Tribunal Superior Eleitoral (TSE), and Tesouro Nacional. The richness of these data allows us to control for a large number of municipal characteristics that are likely to be correlated with corruption practices and whose absence might otherwise confound our estimates. See the data appendix for a detailed description of data sources.

Table 3 compares differences in mean characteristics of municipalities with a first-term to municipalities with a second-term mayor. Because of our lack of experimental design and the need to assume selection on observable characteristics, it is useful to understand if the determinants of corruption are significantly different across the municipalities. As the table demonstrates, there are few differences in observable characteristics between these municipalities. Out of 43 variables, only 5 are significantly different at a 95 percent level of confidence. ${ }^{23}$ There is a significant difference between first and second-term mayors in our measures of electoral performance for the 2000 municipal elections. This is not too surprising given that incumbents tend to have an advantage in elections. The other significant differences are the proportion of the population with at least a secondary school education and the share of the population that lives in urban areas; characteristics that are fairly correlated. In fact, the differences in the share of the urban population loses statistical significant once we account for the differences in secondary school attainment.

\section{$5 \quad$ Empirical Strategy}

Our main objective is to test whether re-election incentives affect the level of political corruption in a municipality. As the theory presented in section 2 predicts, mayors who face re-election incentives should, on average, be less corrupt than those who are no longer eligible for reelection. To estimate the effects of re-election incentives, the ideal experiment would have been to randomly assign the possibility of re-election across municipalities and then measure the differences in corruption levels across these two groups of municipalities among mayors in their first term of office. Unfortunately, this experiment design does not exist and given the cross-

\footnotetext{
${ }^{23}$ We report the 19 most important variables that are later used in our specifications.
} 
sectional nature of our data, we instead compare mayors in their first term, who still face reelection incentives, to second-term mayors using the following regression:

$$
r_{i}=\beta I_{i}+X_{i} \varphi+Z_{i} \gamma+\varepsilon_{i}
$$

where $r_{i}$ is the level of corruption for municipality $i$, and $I_{i}$ indicates whether the mayor is in his first term. The vector $X_{i}$ is a set of municipal characteristics and the vector $Z_{i}$ is a set of mayor characteristics that determine the municipality's level of corruption. The term $\varepsilon_{i}$ denotes unobserved (to the econometrician) municipal and mayor characteristics thought to determine corruption.

In estimating equation 1, we face two main empirical challenges. First, without random assignment of re-election incentives, unobserved characteristics of the municipality and the mayor that affect both re-election and local corruption (e.g. political ability and campaigning effort) will bias a simple OLS regression. Second, even if first and second-term mayor were randomly assigned, the finding that second-term mayors are more corrupt could be due to the fact that they have more experience.

To illustrate these potential biases, consider a simple model that expresses the difference in corruption level between first and second-term mayors in terms of potential outcomes. Let $r_{t}^{D T}$ be the level of rents extracted by a politician at term $t$ in a municipality where mayors can be re-elected to a second term, i.e. a double-term regime, DT. The simple comparison between mayors in their first and second term is:

$$
\Delta=E\left[r_{2}^{D T} \mid \tau=2\right]-E\left[r_{1}^{D T} \mid \tau=1\right]
$$

where $\tau$ denotes a first or second term mayor. Let $r_{t}^{S T}$ denote the levels of rents at term $t$ in a municipality where there are no possibilities of re-election, i.e. a single-term regime, $S T$. We can rewrite this simple difference as:

$$
\begin{aligned}
\Delta & =E\left[r_{2}^{D T} \mid \tau=2\right]-E\left[r_{1}^{S T} \mid \tau=1\right]+\left(E\left[r_{1}^{S T} \mid \tau=1\right]-E\left[r_{1}^{D T} \mid \tau=1\right]\right) \\
& =E\left[r_{2}^{D T} \mid \tau=2\right]-E\left[r_{1}^{S T} \mid \tau=1\right]+\beta
\end{aligned}
$$

where $E\left[r_{1}^{S T} \mid \tau=1\right]$ is the expected level of rent extraction in the first period among first-term mayors who do not face re-election incentives and $\beta$ measures the causal effects of re-election incentives on corruption.

To see the different sources of biases, Equation 2 can be decomposed further as follows:

$$
\Delta=\beta+\underbrace{E\left[r_{2}^{D T} \mid \tau=2\right]-E\left[r_{1}^{S T} \mid \tau=2\right]}_{\text {experience }}+\underbrace{E\left[r_{1}^{S T} \mid \tau=2\right]-E\left[r_{1}^{S T} \mid \tau=1\right]}_{\text {ability }}
$$


The first difference represents the potential bias associate with the effects of political experience on corruption. It compares the corruption level of a second-term mayor in his second-term (i.e. $t=2$ ) of a double-term regime to the amount of corruption the same mayor would have committed in the first period (i.e. $t=1$ ) of a single-term regime. The second difference captures any bias associated with differences in either political ability or unobserved municipal level determinants of corruption. It measures the difference in the amount of corruption between what a second-term mayor would have committed in his first term of a single-term regime and what a first-term mayor commits in the first term of a single-term regime. Thus, assuming that these differences are not zero then the simple OLS estimation of equation 1 will yield biased estimates.

\subsection{Controlling for Political Ability and Other Potential Confounds}

To account for any unobserved differences in either political ability or municipal level characteristics between first and second term mayor, we employ two different identification strategies. First, using a regression discontinuity analysis, we compare municipalities where incumbent mayors barely won reelection in 2000 (and thus served as a second-term mayor from 2001-2004) to municipalities where the incumbent barely lost the election and thus was replaced by a new mayor (who then served as a first term between 2001-2004). As discussed in Lee (2008), close elections provide a quasi-random assignment of municipalities with a first versus second-term mayor. Thus, by comparing elections where the incumbents won or lost by a narrow margin, we control for many of the unobserved characteristics of the municipality that determine both re-election and corruption levels, such as the quality of pool of candidates or the amount of campaign resources. ${ }^{24}$

To exploit the discontinuity in margin of victory which re-elects the incumbent mayor, we modify equation 1 to estimate the following model:

$$
\begin{aligned}
r_{i} & =\beta I_{i}+f\left(W_{i}\right)+X_{i} \varphi+Z_{i} \gamma+\varepsilon_{i} \\
I_{i} & =1\left[W_{i} \geq 0\right]
\end{aligned}
$$

where $W_{i}$ denotes the difference in vote shares between the incumbent and the second place candidate, and $f\left(W_{i}\right)$ is a smooth continuous function of margin of victory. As is typically the case in a regression discontinuity framework, there is a tradeoff between precision and bias, particularly as one moves away from the discontinuity. In section 6 , we present estimates that are robust to various functional form assumptions for $f\left(W_{i}\right)$.

Our second approach addresses differences in unobserved political ability by comparing

\footnotetext{
${ }^{24}$ Dal Bó, Dal Bó, and Snyder (2008), Ferreira and Gyourko (2007), Lee, Moretti, and Butler (2004), Linden (2004) also apply regression discontinuity techniques in the context of elections.
} 
second-term mayors with a subset of first-term mayors that were able to get re-elected in 2004 elections. If the bias from the OLS regression comes from unobserved political ability that positively selects more able politicians into a second-term, this approach controls for a significant portion of this bias by comparing mayors that are as politically able as second-term mayors.

\subsection{Controlling for Experience}

If there is a learning process associated with corruption or if it simply takes time to establish the networks that enable corruption, then the difference in corruption levels between first and second-term mayors may not only reflect re-election incentives but also political experience. ${ }^{25}$

We test for this possibility using two different approaches. First, to account for the fact that second-term mayors are more experienced, we collect data on all mayors who held a political position as either mayor or local legislator during the 1989-1992, 1993-1996, and 1997-2000 administrations and match them to those in power during 2001-2004. We can then compare the corruption of mayors facing a second-term with those mayors serving on a first-term, but who have had previous political experience. Second, we compare first-term mayors to second-term mayors that became candidates in either the governor or legislative elections in 2006. According to theory, second-term mayors who still have career concerns and run for higher offices should behave similarly to first-term mayors. Moreover, such a prediction would be inconsistent with a learning-by-doing hypothesis, where even those second-term mayors with re-election incentives would still be more corrupt than first-term mayors.

\section{Empirical Results}

This section provides evidence that municipalities where mayors face re-election incentives are associated with significantly lower levels of corruption, as measured by the share of resources appropriated. These findings are robust to alternative definitions of corruption, as well as various specifications and estimation techniques. We also explore how re-election incentives vary with local characteristics and find that the effects are stronger among municipalities where the cost of rent extraction are lower and political competition is higher. All these results are consistent with the basic predictions of a standard political agency model. We conclude this section with additional results that address several potential threats to our identification assumptions.

\footnotetext{
${ }^{25}$ As long as reducing corruption increases one chances of getting re-elected then theoretically it is unlikely that any difference between first and second-term mayors is strictly due to a 'learning-by-doing' process.
} 


\section{Basic Results on Corruption}

Table 4 presents regression results from estimating several variants to Equation 1, where the dependent variable is the share of resources that were indicated as corruption. Column 1 reports the unadjusted relationship between whether the mayor is in his first term and the share of funds appropriated. The remaining columns correspond to specifications that include additional sets of controls. The specifications presented in columns 2-4 account for variation in mayors, demographic and institutional characteristics of the municipality, whereas the specifications in columns 5 and 6 include, in addition to the other controls, indicators for when the municipality was selected for audit (lottery intercepts) and state intercepts. The specification presented in column 6, where re-election incentives are identified from only within state and lottery variation, accounts for any state-specific or lottery-specific unobservable that might have affected political corruption. It also controls for any differences across states (and in effect across time) for how the municipalities may have been audited.

From the bivariate relationship in column 1, we see that first-term mayors are associated with a 2.0 percentage point decrease in corruption. At an average corruption level of 0.074 among second-term mayors, this estimate represents a 27 percent decline. As seen in the other columns, the inclusion of additional controls has a minimal effect on the point estimate. For example in column 6, which controls for state and lottery intercepts and various mayor and municipal characteristics, including the amount of resources transferred to the municipality, the estimated effect is slightly larger in magnitude (point estimate $=-0.027$; and standard error 0.011), but statistically indistinguishable from the estimate of the unadjusted regression $(\mathrm{F}(1$, $409)=0.44 ; \mathrm{P}$-value $=0.5076)$. If we consider that on average $\mathrm{R} \$ 5,459,054$ was transferred to these municipalities, lame-duck mayors misappropriate approximately $\mathrm{R} \$ 148,000$ (US $\$ 60,000$ ) more than first-term mayors.

Columns 7 and 8 of Table 4 present the estimated effect of re-election incentives based on different functional form assumptions. In column 7, we display the estimated effects for our corruption measure using a bias-adjusted matching estimator (Abadie and Imbens 2006). Although compared to the regression analysis the identification assumptions are similar, the matching estimator has the advantage that it neither assumes a functional form nor extrapolates over areas of uncommon support in the observable characteristics. In addition, to the matching estimator, we also estimate a Tobit model to account for the left censoring of municipalities with zero share of corruption (displayed in the column 8). For each alternative specification, the point estimates are consistent to the OLS estimates presented in the other columns. Using the Tobit model, the marginal effects for the entire sample increase in magnitude to -0.042 (standard error $=0.012$ ) compared to -0.027 (standard error $=0.011$ ) in the OLS regression.

Table 5 reports the estimated effect of re-election incentives using our two alternative measures of corruption. Columns 1-4 compares the number of irregularities associated with cor- 
ruption between first and second-term mayors, whereas columns 5-8 estimate the relationship for the share of service items related to corruption (number of corrupt irregularities divided by the number of audited items). For each measure, we report the unadjusted relationship, the most complete model, and alternative functional forms. Under our full specification, first-term mayors are associated with 0.467 fewer acts of corruption (column 2). When compared to average corruption among second-term mayors, this effect represents a 22 percent decline. We also find that first-term mayors are significantly less corrupt when measured by the share of service items found to be corrupt. ${ }^{26}$ By this measure, first-term mayors are 23 percent less corrupt than second-term mayors. As the remaining columns demonstrate, these estimates are robust to alternative specifications and estimation procedures. Together these findings suggest that mayors who still face the possibility of re-election engage in less corrupt activities than mayors who may have a shorter political horizon.

\section{Accounting for Political Ability and Other Potential Confounds}

Thus far, our results show that there is less corruption in municipalities governed by firstterm mayors. Although this is consistent with the effects of re-election incentives, there are alternative interpretations for these findings. One possibility is that our estimates are capturing some unobserved characteristics of the municipality or the mayor that increases both re-election rates and corruption levels. For instance, first and second-term mayors might differ in political ability. If a mayor's ability increases his re-election probability and enables him to be more corrupt, then our estimates are potentially biased upwards.

In this section, we address these concerns using two approaches. First, we identify the effects of re-election incentives using elections where the incumbents won or lost by a narrow margin. As we discussed in Section 5, this regression discontinuity approach provides quasirandom assignment of first-term mayors (municipalities where incumbents barely lost re-election) and second-term mayors (municipalities where incumbents barely won re-election) for the subset of municipalities where the incumbent ran for re-election. ${ }^{27}$ In addition to the RDD approach, we also present estimates where we compare second-term mayors to a subset of first-term mayors that were able to get reelected at the end of their terms. If the bias from the OLS regression comes from unobserved political ability that positively selects more able politicians into a secondterm, this approach controls for a significant portion of this bias by comparing mayors that are as politically able as second-term mayors.

\footnotetext{
${ }^{26}$ This measure addresses the concern that municipalities with second-term mayors may have had more items audited. Alternatively, when we control for the number of service items audited in the specifications presented in columns 1-4, the estimate remain almost identical.

${ }^{27}$ Note that this identification strategy still does not allow us to disentangle the effects of re-election incentives from a simple model of learning by doing. It also does not control for underlying differences in the individual politicians. We account for these possibilities in the next set of robustness checks.
} 
Results from these two approaches are shown in Table 6. In columns 1-3 we present results from a Regression Discontinuity Design specification where the running variable is the difference in vote share between the incumbent and the runner-up (or the winner if the incumbent lost the election). ${ }^{28}$ In column 2 we control linearly for the difference in vote shares while in columns 3 and 4 we include a quadratic and a cubic term respectively. The results are robust to these various functional form assumptions with the coefficient on the first-term indicator varying between 0.029 and -0.037 (standard errors varying from 0.017 to 0.020 ). For instance, allowing for a cubic polynomial in the incumbent's margin of victory, we see that compared to second-term mayors, first-term mayors are 3.7 percentage points less corrupt. ${ }^{29}$

The results from comparing the corruption levels of second-term mayors to the set of firstterm mayors that get re-elected are presented in columns 4 and 5 of Table 6 . The coefficient on the first-term indicator increases in magnitude to -0.040 (standard error $=0.013$ ), suggesting that second-term mayors extract a higher level of rents from office even compared to first-term mayors of similar political ability. It is important to note however that the larger coefficient on the first-term dummy was expected because the dissemination of the audit program decreased the probability that corrupt mayors were re-elected (see Ferraz and Finan (2008)). To control for the effects of the audits, we use an alternative strategy where we estimate the probability of re-election using the sample of mayors that were audited only after the 2004 elections (and hence voters did not have this information) and compute the predicted probability of a first-term mayor getting re-elected. ${ }^{30}$ After controlling for the effects of the audits, the point estimate reduces to -0.034 (standard error 0.017) and is still significant at 90 percent confidence.

\section{Controlling for Experience and Learning-by-Doing}

Politicians in power for a longer period of time may learn corruption practices and establish networks that enable them to be more corrupt. If this was the case, the estimated differences

\footnotetext{
${ }^{28}$ The sample size drops to 328 because some incumbents in 2000 do not run for reelection. Although this is a select sample, column 1 in Appendix Table 1 replicates our main specification that compares first and secondterms excluding municipalities where the incumbent did not run in the 2000 election. The estimated effect (point estimate $=-0.02 ;$ standard error $=0.011)$ is similar both statistically and in magnitude to the effect for the overall sample.

${ }^{29} \mathrm{We}$ also estimate alternative specifications where we allow the slope to vary across each side of the zero vote margin discontinuity with a linear, quadratic and cubic splines. The results are shown in table 1 in the Appendix and provide similar coefficients, although we lose some precision in the point estimates due to the small sample. Results for the other measures of corruption display similar patterns and are available upon request.

${ }^{30} \mathrm{We}$ constructed a propensity score for whether the mayor was re-elected in the 2004 elections using various mayor and municipal characteristics. These characteristics included: the mayor's gender, education, marriage status, age, and party affiliation dummies; the municipality's log population, population with secondary school education, age of municipality, log GDP per capita, income equality, share of the legislative branch that supports the mayor, effective number of parties in 2000 election, an indicator for whether there is a judge in the municipality, state fixed effects. The predicted indicator is equal to one if the propensity score was greater than or equal to 0.5 . The estimation predicted 64 percent of the cases correctly.
} 
in corruption between first and second-term mayors might just reflect the corruption know-how accumulated over time rather than the effects of re-election incentives. In this section we provide evidence that although second-term mayors have more political experience, these additional years in office cannot fully explain the differential corruption of first and second-term mayors. ${ }^{31}$

We start by identifying the 2001-2004 mayors who were either in power during the 1989-1992, 1993-1996 administrations or served as local legislators during the 1997-2000 administration. ${ }^{32}$ If the difference in corruption levels between first and second-term mayors is largely due to experience then we would expect first-term mayors who had previously been in power to have similar corruption levels to second-term mayors. In column 1, Table 7, we re-estimate our basic specification, but control for an indicator for whether the first-term mayor was in power in one of the three previous terms (12 years). The point estimate of -0.031 (standard error $=0.012$ ) is almost identical to the original point estimate of -0.027 in column 6 , Table $4 .^{33}$

An alternative way to account for previous experience is to compare second-term mayors with only first-term mayors who have previously been in power. Hence, we re-estimate the baseline regression using all second-term mayors, but restrict first-term mayors to only those that have been mayors before (either from 1988-1992 or 1993-1996). The coefficient on first-term, shown in Table 7, column 2, is -0.039 (standard error $=0.014$ ) further suggesting that political experience does not entirely drive the difference in corruption levels between first and second-term mayors.

One potential criticism to this approach is that the political networks built by a mayor during 1992-1996 might be lost when he spends time away from office before returning in 2001. Hence, we compute an alternative measure of political experience where we also take into account firstterm mayors that served as local legislators during the previous administration (1996-2000). ${ }^{34}$ In column 3, Table 7, we re-estimate the basic model comparing second-term mayors to firstterm mayors that have had previous political experience, including experience as local legislators during the previous term. The estimated difference in corruption between first and second-term mayors decreases slightly to 2.9 percentage points (standard error=0.016). Finally, in column 4 of Table 7, we compare the corruption level of second-term mayors to first-term mayors that have previously been in power and are high ability mayors (were re-elected in the 2004 election). The coefficient estimated on the first-term dummy is again -0.056 (standard-error $=0.018$ ). ${ }^{35}$

\footnotetext{
${ }^{31}$ In fact, the possibility of re-election was only introduced in 1997, but mayors could be re-elected after a one-term hiatus. One concern is that in effect mayors do not face term limits because they can run again after being out for one-term. For our purposes, this mis-measurement of the politician's political horizon implies that we would be underestimating the effects of re-election incentives.

${ }^{32}$ Since these data are not available on electronic format, we called each one of the 26 state level electoral courts (TRE) and obtained the names of elected mayors in the 1988 and 1992 elections. We could not obtain records before 1988 since they are not systematically recorded across states.

${ }^{33}$ Although not reported, all of the results presented in this section, as well as the others, are similar when using the other corruption measures.

${ }^{34}$ There are 27 (11 percent) first-term mayors that served as local legislators from 1996-2000.

${ }^{35}$ If we use the predicted indicator for re-election our point estimate falls to -0.043 (standard error $=0.028$ ), which although measured with less precision, is again consistent with the other estimates.
} 


\section{Corruption and Future Career Concerns}

We have interpreted the coefficient on the first-term indicator as evidence that mayors who face re-election incentives engage, on average, in less corrupt activities. Second-term mayors however may have other political aspirations and it is often the case that some mayors in Brazil continue their political careers as state level legislators or federal deputies. ${ }^{36}$ The theory would therefore suggest that second-term mayors who still have career concerns and run for higher offices should behave similarly to first-term mayors. To test this, we gather data from the 2006 governor and legislative elections and match the names of candidates to those mayors that were in power from 2001-2004. Out of the 485 mayors in power during the 2001-2004 term nine percent ran for office in 2006 .

In column 5 of table 7 , we restrict the sample to only second-term mayors and run a regression of corruption on an indicator for whether the second-term mayor ran for a higher level office in 2006. Again as the theory suggests, we find that second-term mayors with career concerns are 4.9 percentage points less corrupt than second-term mayors without career concerns.

While these estimates support a model of re-election incentives, one potential problem with this test is that the decision to run for a higher-level office might be endogenous to the level of corruption uncovered in the audits. While we acknowledge that this result should be interpreted with caution, accusations of corruption and crimes in Brazil seem to have greater impacts on local elections compared to national elections and it is unlikely that accusations of local corruption will affect nominations for high level offices ${ }^{37}$ - for instance, approximately 35 percent of federal congressmen and 30 percent of senators are accused of crimes that were committed before taking office. $^{38}$

\section{Local Context and Re-election Incentives}

In this section we explore the extent to which the effects of re-election incentives on corruption might vary according to local characteristics that affect electoral accountability. In order to shed light on the empirical results, we start by discussing some natural extensions to the simple model presented in Section 2. The asymmetry of information between voters and politicians lies at the heart of political agency models. Hence, factors that influence access to information may affect how re-election incentives affect corruption. ${ }^{39}$ Suppose for instance that with some probability voters observe their politician's type after he has chosen his action and before the election is held. As the likelihood that a corrupt politician is detected in the first period increases (i.e. voters have

\footnotetext{
${ }^{36}$ In the 2006 election, for example, out of the 246 newly elected deputies, 13 percent were ex-mayors (BBC Brazil).

${ }^{37}$ Even though Ferraz and Finan (2008) find that the audit reports reduced the likelihood of reelection on among mayors, they do not find evidence that the audits reduced the likelihood of running for re-election.

${ }^{38}$ See the report from Transparencia Brasil at: http://www.excelencias.org.br/excelencias.pdf .

${ }^{39}$ The framework used for discussing the effects of information on corruption is based on Besley (2006).
} 
more information), a corrupt politician will be less likely to pool with non-corrupt politicians, and hence discipline will be reduced. But as corrupt politicians become less disciplined, they are less likely to survive into a second-period and the quality of the average politician that survives into a second-mandate improves. Hence, the overall effect of an increase of information that allows voters to identify politicians' type is ambiguous- corruption will decrease in the second period and potentially increase in the first because those corrupt mayors will now extract as much rent as they can in the first period. Empirically, with a cross-section of mayors, one would expect that the difference in corruption between first and second-term mayors to be smaller in municipalities where there is more access to information that allows voters to uncover the politician's type (e.g. presence of local radio).

An additional source of heterogeneity stems from differences across municipalities in the potential punishment of engaging in corruption. For instance, the probability of being prosecuted and punished for corruption charges is likely to be higher in municipalities where the judiciary has a public prosecutor, thus increasing the cost of engaging in corrupt activities. As corruption costs increase, thus reducing the future benefits of rent extraction, politicians will become less disciplined and the selection effect will increase. Therefore, we would expect that in municipalities where the costs of engaging in corruption are higher, the difference in corruption between first and second-term mayors will also be lower.

Political competition may also determine how re-election incentives affect corruption. An increase in electoral advantage will reduce the disciplining effect, as the probability of being re-elected increases, even if the corrupt mayor does not pretend to be non-corrupt. Thus, the difference between first and second-term mayors is less in municipalities where the elections are less competitive.

Finally, a mayor's political support might affect corruption choices. If the mayor has a majority in the local legislature, he will be able to pass legislations, increase public employment and adopt other strategies that increase his re-election chances. Everything else constant, he can be less disciplined and still get reelected into a second-term. Thus, we expect the difference in corruption between first and second term mayors to decrease as the support in the local legislature increase.

In Table 8 we show the results using as proxies for these local characteristics: the presence of a judge, the existence of local radio, political competition, and the share of local legislators that belong to the same party as the mayor. ${ }^{40}$

The presence of public prosecutors or a local media reduces the corruption differential between first-term and second-term mayors. Among municipalities with public prosecutors, there is only

\footnotetext{
${ }^{40} \mathrm{In}$ Brazil, the presence of a judge depends on whether the unicipality is a judiciary district (comarca), which in turn depends on local characteristics such as population, local revenues and the number of judiciary processes. The presence of local radios have an important effect in revealing the type of politician, see Ferraz and Finan (2008).
} 
a small difference in corruption levels between first and second-term mayors (column 1), and in municipalities with local media - in the form of either radio or newspaper - the difference is only 1.4 percentage points (column 2). In contrast, among municipalities where there does not exist any local media, second-term mayors are almost 10 percentage points (standard error $=0.03$ ) more corrupt than first-term mayors, which represents an average $\mathrm{R} \$ 523,000$ (US\$237,592).

Columns 3 and 4 report how the second-term effect varies with the degree of political competition, as measured by the proportion of the local council that is from the same party as the mayor (column 3) and a political Herfindahl index in the previous election (column 4). ${ }^{41}$ As reported in column 3, political competition increases the difference in corruption levels between first and second-term mayors. When only 9 percent of the legislative council is from the same political party as the mayor (5th percentile of the distribution), there an 8.8 percentage point difference between first and second-term mayors. Whereas, when the political support of the incumbent mayor represents 55 percent of the legislative branch, then there is no difference in corruption levels between first and second-term mayors. The results reported in Column 4 tell a similar story. For instance, among municipalities where the Hefindahl index was 0.08 (the 1st percentile of the distribution), first-term mayors are 3.9 percentage points less corrupt that second-term mayors. In contrast, when elections are less competitive at 0.528 (the 99 percentile of the distribution), the difference in corruption levels between first and second-term mayors is -0.007. In effect, the results presented in columns (3) and (4) suggest that municipalities characterized by low competition exhibit no differential effect in rent-extraction between first and second-term mayors. First-term mayors with an extreme electoral advantage can afford to be as corrupt as a lame-duck mayor since his re-election is practically guaranteed.

\section{Discussion}

Our analysis shows that mayors who can be held accountable at the polls will engage in less corruption. First-term mayors misappropriate 27 percent less resources than second-term mayors even when accounting for potential biases in political ability and experience. Our findings support a political agency model where mayors with re-election incentives refrain from rent extraction in order to increase their likelihood of re-election.

An obvious concern in interpreting the relationship between re-election incentives and corruption is that it may simply reflect corruption on the part of the auditors. Because first-term mayors have more incentive to bribe the auditors for a more favorable report, we could be capturing the effects of re-election incentives on bribing rather than the effects of career concerns on actual corruption. While it is difficult to test this hypothesis directly, we provide suggestive evidence that this is not the case. For instance, if first-term mayors are more likely to bribe au-

\footnotetext{
${ }^{41}$ The Herfindahl index is computed by dividing one by the effective number of political parties.
} 
ditors, we might expect first-term mayors who were audited during the election year or affiliated with either the federal government or state government to receive more favorable reports.

We explore these possibilities in Table 9. In columns 1-3 we regress our measure of corruption on the first-term indicator and interaction terms with variables that would suggest larger incentives for bribing the auditors. In column 1 we test for differential auditing according to whether the municipality was drawn to be audited during the 2004 election year. We show that there is no difference in corruption levels between first and second-term mayors depending on whether they were audited during the electoral year or not (coefficient $=0.001$, standard error $=0.017$ ). We also do not find any differential effects by whether the mayor belongs to the same party of the president - the PT (Worker's Party) - (column 2) or the state governor (column 3). ${ }^{42}$ An alternative way in which auditors may have favored first-term mayors could have been to audit less valued projects. Although this is unlikely to explain the patterns that we find in the main regressions, we regress the value of projects audited, expressed in logarithms, on an indicator for whether the mayor is in a first-term. As reported in column 4, we again do not any find statistically significant differences in the amount of resources audited between first and second term-mayors and do not find a differential effect if the municipality was audit during the 2004 electoral year (column 5).

In addition to the previous analysis, there are several reasons why it is unlikely that differences in corruption between first and second-term mayors reflect corrupt auditors. First, they are federal public employees hired based on a highly competitive public examination and high salary. Moreover, each team of auditors reports to a regional supervisor. Therefore, not only is it hard to cheat individually, but also the cost of getting caught is large. According to program officials, there has never been an incidence in which auditors have even been caught receiving bribes. ${ }^{43}$

Another explanation for the difference in reported corruption levels is that lame duck mayors, who are no longer accountable to voters, simply have less incentive to hide or are less careful in their attempt to hide corruption. Although this hypothesis is in many respects observationally equivalent to what we find, it is unlikely that this could explain the estimated effects since this program was unexpected and the audits were based on past behavior. Moreover, although second term mayors may not face electoral retribution, they also have an incentive to hide corruption due to potential judiciary prosecution.

Finally, given our findings, it is natural to ask whether a two-term limit system is optimal to reduce the incentives for rent-extraction. Although Smart and Sturm (2006) provide theoretical justification for why a two-term limit regime might be optimal under some conditions, we are unfortunately unable to test this. Unlike the variation that exists in term-limits across the U.S.,

\footnotetext{
${ }^{42}$ Ferraz and Finan (2008) compare corruption levels using the count measure between first-term mayors that were audited before the election versus after the election. It does not find any evidence that corruption levels differed between these two groups along various dimensions.

${ }^{43}$ Based on the interviews conducted by the authors with program officials in Brasilia.
} 
our research design can only identify the effects of re-election incentives on corruption under a two-term regime relative to a one-term regime. We cannot estimate for instance how politicians would behave if they were elected for a third term or even re-elected indefinitely.

\section{Conclusions}

Voters have imperfect information about politicians' actions. Thus, the incentives provided by elections act as a disciplining device to constrain politicians' malfeasance. In this paper we test whether political institutions that provide electoral accountability through the possibility of reelection reduces corruption. We build a new dataset of corruption practices by local politicians in Brazil using reports from an ambitious anti-corruption program designed to audit a municipality's use of federal funds. We exploit the variation in electoral incentives provided by term limits and show that first-term mayors are associated with significantly less corruption than second-term mayors, as measured by either the share of resources misappropriated, the share of service items related to corruption, or the number of corrupt irregularities. The reduction in corruption practices induced by electoral accountability is not only statistical significant, but economically important. Assuming that, in the absence of re-election incentives, first-term mayors would behave as second-term mayors, we estimate that re-election incentives are responsible for inducing a reduction in resources misappropriated in the order of $\mathrm{R} \$ 433$ million (US $\$ 160$ million). This is more than half of what the federal government spent in the Bolsa Escola conditional cash transfer program for all municipalities in Brazil during 2002.

The difference in corruption between first and second-term mayors is remarkably robust to various specifications and alternative interpretations. We show that there is more corruption in municipalities governed by second-term mayors even when compared to first-term mayors that have been in power in a previous mandate (experienced politicians). Our findings also suggest that the effects of re-election incentives on corruption depend on local characteristics. The estimated differential effect between first and second-term mayors is more pronounced among municipalities where the cost of corruption is higher - as measured by the presence of a judge and also where access to information and political support is lower. We also find that secondterm mayors facing term-limits who later pursue further a political career behave as first-term mayors and engage in less corrupt activities.

These results can be explained by a simple political agency model similar to Besley (2006) and Smart and Sturm (2006) where the possibility of re-election creates both discipline and selection effects. Although second-term mayors face a shorter political horizon and thus have less incentive to accommodate voters' preferences, rational voters will elect into a lame-duck term politicians that are less corrupt than average. Hence, such a positive selection may counteract any adverse incentive effect induced by term-limits. Our analysis tries to account for the importance of 
this selection effect by comparing second-term mayors with first-term mayors that later got reelected into a second term and shows that second-term mayors are significantly more corrupt. We interpret this as evidence that, in the context of Brazil's local governments, the discipline effect dominates the selection effect inducing first-term mayors with re-election incentives to extract fewer rents from power. ${ }^{44}$

Overall, the findings suggest that electoral rules that enhance political accountability play a crucial role in constraining politician's corrupt behavior even in an institutional context where corruption is pervasive and elites dominate local politics. Despite this positive effect of re-election incentives on constraining corruption, further research is needed in order to assess whether electoral accountability affects other aspects of governance and ultimately improves voters' welfare.

\footnotetext{
${ }^{44}$ Our results also complement Alt, de Mesquita, and Rose (2007) who examines the accountability and selection effects for the case of fiscal policy in the U.S. using variation in term-limits across governors.
} 


\section{Appendix A: Coding the Audit Reports}

This appendix explains how we used the audit reports to construct indicators of corruption. We provide the definition used for each type of irregularity and include an illustrative example drawn from the reports. ${ }^{45}$

\section{Examples of Political Corruption}

Health related purchases without procurement using false receipts: The ministry of Health transferred to the municipality $\mathrm{R} \$ 321,700$ for the Programa de Atenção Bsica. The municipal government used fake receipts valued at $\mathrm{R} \$ 166,000$ to provide proof of purchase. Furthermore, there is no proof that the goods were purchased since there were no registered entries of the merchandize in the stock. Also, in 2003 the municipality bought medicines valued at $\mathrm{R} \$ 253,300$ without procurement. In 2004 , the value was $\mathrm{R} \$ 113,700$, also without procurement. We classified this violation as an incidence of irregular procurement and diversion of public funds in the area of health. We valued this irregularity as a diversion of $\mathrm{R} \$ 166,000$. This irregularity occurred in Capelinha, Minas Gerais, drawn by lottery number 9 .

Evidence of irregularities in well construction: The Ministry of National Integration transferred $\mathrm{R} \$ 117,037$ to the municipality for the maintenance of water infra-structure. The working plan specified the maintenance of ten wells and four dams. None of these repairs were made. Instead, the dam Henrique Dantas, located inside a private farm was repaired. We classified this violation as an incidence of diversion of public funds in the area of water and sanitation. We valued this irregularity as a diversion of $\mathrm{R} \$ 117,037$. This irregularity occurred in Santa Cruz, Rio Grande do Norte, drawn by lottery number 9.

Over-invoice of more than $\mathbf{R} \$ 3$ million in road construction: The firm Mazda was hired, without procurement, to build approximatly nine kilometers of a road. The cost of the construction was estimated at $\mathrm{R} \$ 1$ million based on similar constructions. The receipts presented by Mazda and paid by the government totalled $\mathrm{R} \$ 5$ million. No further documentation was shown by the municipal government proving the need for the additional amount of resources. The auditors found that the firm Mazda, did not have any experience with construction and had sub-contracted the firm CTE for $\mathrm{R} \$ 1.8$ million to do the construction. Hence, the project was over paid by more than $\mathrm{R} \$ 3$ million. As evidence of corruption, it was late found that the firm Mazda gave an apartment for the mayor and his family valued at $\mathrm{R} \$ 600,000$ suggesting a kickback. We classified this violation as an incidence of over-invoice in the area of infrastructure. We valued this irregularity as a

\footnotetext{
${ }^{45}$ For access to the summary of the audit reports, see www.cgu.gov.br
} 
diversion of $\mathrm{R} \$ 3.2$ million. This irregularity occurred in São Francisco do Conde, Bahia, drawn by lottery number 6 .

\section{Appendix B: Data Sources}

The data used in the paper comes from a variety of sources. The data is at the level of the municipality, the lowest government unit below a state in Brazil.

Municipal demographic characteristics: The 2000 population census provides socio-economic and demographic characteristics of municipalities. The variables we include in our analysis are: population size, percentage of urban households, Gini coefficient and the percentage of adults with secondary education. In addition, we also include the level of income measured by municipal GDP per capita estimated by the IBGE. These variables are important determinants of corruption as shown by Glaeser and Saks (2006) and Treisman (2000).

Municipal institutional and public management characteristics: Our second complementary data source from IBGE is a municipality survey, Perfil dos Municípios Brasileiros: Gestão Pública, conducted in 1999 and 2001. The survey provides structural features of the municipality such as the existence of local daily newspaper, radio, local public prosecutors and the age of the municipality. These data also characterize various aspects of the public administration, including the existence of laws which govern its budgetary and planning procedures.

Election data: Results from 2000 and 2004 mayor elections are available from the Tribunal Superior Eleitoral (TSE). These data contain vote totals for each candidate by municipality, along with various individual characteristics such as the candidate's gender, education, occupation, and party affiliation. We use this information to construct measures of electoral performance, and to control for individual mayor characteristics that might affect corruption. We also use the TSE data to build measures of mayor's political support in the local legislature as well as the size of the legislature.

Public finance data: Finally, we use public finance data, FINBRA, from the Tesouro Nacional (National Treasury) to construct a measure of intergovernmental transfers received by municipalities. These data control for potential differences in the amount of resources received from the state and federal governments across municipalities. 


\section{References}

Abadie, Alberto, and Guido Imbens. 2006. "Large Sample Properties of Matching Estimators for Average Treatment Effects." Econometrica 74 (1): 235-267.

Adsera, Alicia, Carles Boix, and Mark Payne. 2003. "Are You Being Served? Political Accountability and the Quality of Government." The Journal of Law, Economics, and Organization 19, no. 2 (445-490).

Alt, James, Ethan Bueno de Mesquita, and Shanna Rose. 2007. "Accountability, Selection, and Term Limits: Theory and Evidence from US State Elections." Working paper.

Bandiera, Oriana, Andrea Prat, and Tommaso Valletti. 2007. "Active and Passive Waste in Government Spending: Evidence from a Policy Experiment." Forthcoming in American Economic Review.

Banks, Jeffrey, and R. Sundaram. 1993. "Adverse Selection and Moral Hazard in a Repeated Elections Model." In Political Economy: Institutions, Information, Competition, and Representation, edited by et al W. Barnett. Cambridge and New York: Cambridge University Press.

Barro, Robert. 1970. "The Control of Politicians: An Economic Model." Public Choice 14:1942.

Bertrand, Marianne, Simeon Djankov, Rema Hanna, and Sendhil Mullainathan. 2007. "Does Corruption Produce Unsafe Drivers?" Quarterly Journal of Economics CXXII (4): 16391676 (November).

Besley, Timothy. 2006. Principled Agents? The Political Economy of Good Government. Oxford, UK: The Lindahl Lectures, Oxford University Press.

Besley, Timothy, and Anne Case. 1995. "Does Electoral Accountability Affect Economic Policy Choices? Evidence from Gubernatorial Term Limits." The Quarterly Journal of Economics 110 (3): 769-798 (August).

Besley, Timothy, and Michael Smart. 2007. "Fiscal Restraints and Voter Welfare." Journal of Public Economics 91 (3-4): 755-773 (April).

Campante, Filipe R., Davin Chor, and Quoc-Anh Do. 2006. "Instability and the Incentives for Corruption." Mimeo, Harvard University.

Dal Bó, Ernesto, Pedro Dal Bó, and Jason Snyder. 2008. "Political Dynasties." forthcoming Review of Economic Studies.

Di Tella, Rafael, and Ernesto Schargrodsky. 2003. "The Role of Wages and Auditing During a Crackdown on Corruption in the City of Buenos Aires." Journal of Law and Economics 46 (1): 269 . 
Duggan, Mark, and Steven D. Levitt. 2002. "Winning Isnt Everything: Corruption in Sumo Wrestling." American Economic Review 92 (5): 1594605.

Ferejohn, J. 1986. "Incumbent Performance and Electoral Control." Public Choice 50:5-25.

Ferraz, Claudio, and Frederico Finan. 2007. "Corruption in Local Governments: Evidence from Audit Reports." Mimeo, UCLA.

- 2008. "Exposing Corrupt Politicians:The Effects Of Brazils Publicly-released Audits on Electoral Outcomes." Quarterly Journal of Economics 123 (3): 703-745 (May).

Ferreira, Fernando, and Joseph Gyourko. 2007. "Do Political Parties Matter? Evidence from U.S. Cities." Forthcoming in Quarterly Journal of Economics.

Fisman, Raymond. 2002. "Estimating the Value of Political Connections." American Economic Review 91 (4): 10951102.

Fisman, Raymond, and Shang-Jin Wei. 2004. "Tax Rates and Tax Evasion: Evidence from Missing Imports in China." Journal of Political Economy 112:471-496.

Glaeser, Edward L., and Raven E. Saks. 2006. "Corruption in America." Journal of Public Economics 90:1053-1072.

Knack, Stephen, and Philip Keefer. 1995. "Institutions and Economic Performance: CrossCountry Tests Using Alternative Institutional Measures." Economics and Politics 7 (3): $207-227$.

Kunicová, Jana, and Susan Rose-Ackerman. 2005. "Electoral Rules and Constitutional Structures as Constraints on Corruption." British Journal of Political Science 35, no. 4 (October).

Lederman, Daniel, Norman Loayza, and Rodrigo Reis Soares. 2005. "Accountability and Corruption: Political Institutions Matter." Economics and Politics 17 (1): 1-35 (March).

Lee, David S. 2008. "Randomized Experiments from Non-random Selection in U.S. House Elections." Journal of Econometrics 142 (2): 675-697.

Lee, D.S., E. Moretti, and M. Butler. 2004. "Do Voters Aect or Elect Policies? Evidence from the U.S. House." Quarterly Journal of Economics 119:807-859.

Linden, Leigh L. 2004. "Are Incumbents Always Advantaged? The Preference for NonIncumbents in India." Working paper.

List, John A., and Daniel M. Sturm. 2006. "How Elections Matter: Theory and Evidence from Environmental Policy." Quarterly Journal of Economics 121 (4): 1249-1281 (November).

Mauro, Paolo. 1995. "Corruption and Growth." Quarterly Journal of Economics, no. 110:681712. 
Myerson, Roger. 1993. "Effectiveness of Electoral Systems for Reducing Government Corruption: A Game Theoretical Analysis." Games and Economic Behavior 5:118-132.

Olken, Benjamin A. 2007. "Monitoring Corruption: Evidence from a Field Experiment in Indonesia." Journal of Political Economy 115, no. 2 (April).

Persson, Torsten, Gerard Roland, and Guido Tabellini. 1997. "Separation of Powers and Political Accountability." The Quarterly Journal of Economics 112 (4): 1163-1202 (November).

Persson, Torsten, and Guido Tabellini. 2000. Political Economics: Explaining Economic Policy. Cambridge, Massachussets: MIT Press.

Persson, Torsten, Guido Tabellini, and Francesco Trebbi. 2003. "Electoral Rules and Corruption." Journal of the European Economic Association 1, no. 4 (June).

Reinikka, Ritva, and Jakob Svensson. 2004. "Local Capture: Evidence from a Central Government Transfer Program in Uganda." Quaterly Journal of Economics 119 (2): 679-705 (May).

Rose-Ackerman, Susan. 1999. Corruption and Government: Causes, Consequences, and Reform. New York: Cambridge University Press.

Smart, Michael, and Daniel M. Sturm. 2006. "Term Limits and Electoral Accountability." CEPR Discussion Paper 4272, July.

Svensson, Jakob. 2003. "Who Must Pay Bribes and How Much? Evidence from a Cross-Section of Firms." Quarterly Journal of Economics CXVIII (February): 207-230.

Treisman, Daniel. 2000. "The causes of corruption." Journal of Public Economics, vol. 76.

Trevisan, Antoninho M., Antonio Chizzotti, Joao Alberto Ianhez, Jose Chizzotti, and Josmar Verillo. 2004. O Combate à Corrupção nas Prefeituras do Brasil. São Paulo, Brasil: Ateliê Editorial.

VEJA. 2004. "Pragas Urbanas: Desperdício, Desvio e Corrupção." 
Table 1: Summary Statistics of Corruption by Type

\begin{tabular}{|c|c|c|c|c|}
\hline & \multicolumn{4}{|c|}{ Type of irregularity } \\
\hline & $\begin{array}{c}\text { Diversion of } \\
\text { funds }\end{array}$ & $\begin{array}{c}\text { Illegal } \\
\text { procurement }\end{array}$ & $\begin{array}{c}\text { Over } \\
\text { invoicing }\end{array}$ & $\begin{array}{c}\text { Corruption } \\
\text { indicator } \\
\end{array}$ \\
\hline Proportion of municipalities with at least one irregularity & $\begin{array}{c}0.535 \\
(0.500)\end{array}$ & $\begin{array}{c}0.571 \\
(0.490)\end{array}$ & $\begin{array}{c}0.069 \\
(0.253)\end{array}$ & $\begin{array}{c}0.780 \\
(0.414)\end{array}$ \\
\hline Conditional on at least one irregularity & & & & \\
\hline Average number of irregularities & $\begin{array}{c}1.688 \\
(1.008)\end{array}$ & $\begin{array}{c}1.673 \\
(0.952)\end{array}$ & $\begin{array}{c}1.029 \\
(0.174)\end{array}$ & $\begin{array}{c}2.471 \\
(1.556)\end{array}$ \\
\hline Average value of irregularity ( $\mathrm{R} \$ 1000)$ & $\begin{array}{l}106.28 \\
(263.9)\end{array}$ & $\begin{array}{l}175.85 \\
(274.2)\end{array}$ & $\begin{array}{l}100.18 \\
(209.2)\end{array}$ & $\begin{array}{l}124.91 \\
(180.5)\end{array}$ \\
\hline Share of audited resources related to corruption & $\begin{array}{c}0.043 \\
(0.073)\end{array}$ & $\begin{array}{c}0.083 \\
(0.099)\end{array}$ & $\begin{array}{c}0.026 \\
(0.044)\end{array}$ & $\begin{array}{c}0.087 \\
(0.111)\end{array}$ \\
\hline Share of audited items related to corruption & $\begin{array}{c}0.046 \\
(0.034)\end{array}$ & $\begin{array}{c}0.046 \\
(0.028)\end{array}$ & $\begin{array}{c}0.029 \\
(0.012)\end{array}$ & $\begin{array}{c}0.068 \\
(0.048)\end{array}$ \\
\hline
\end{tabular}

Notes: This table reports descriptive statistics on the various measures of corruption. These statistics were only computed for the 492 municipalities. Standard deviations are reported in parentheses. 
Table 2: Summary Statistics of Corruption by First and Second-term Mayors

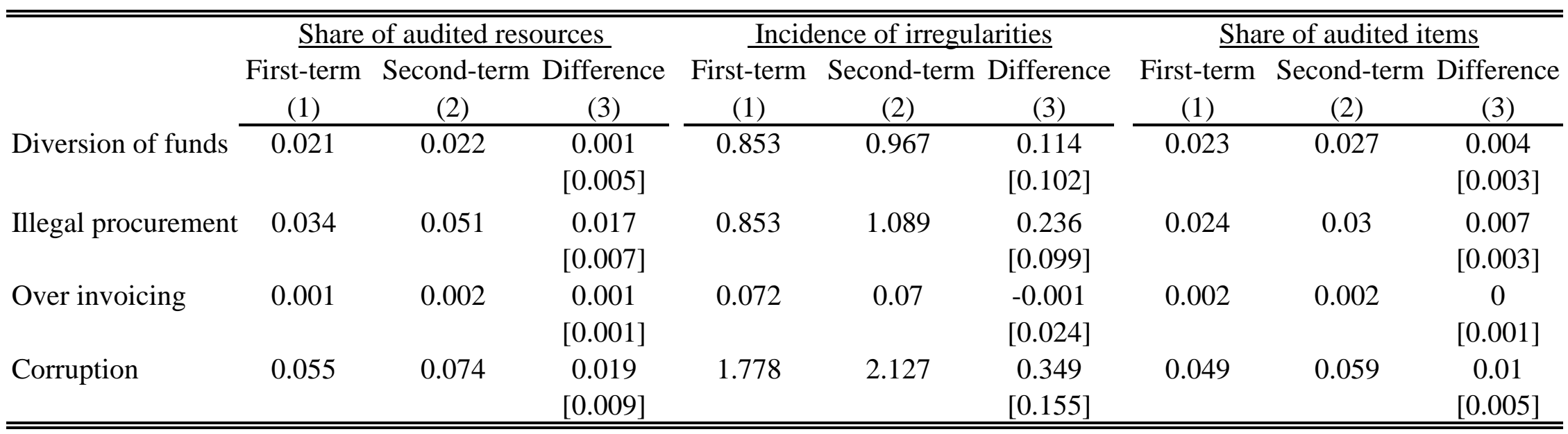

Notes: This table compares the various measures of corruption between first and second-term mayors. These statistics were only computed for the 492 municipalities. Column 1 reports the means for the 279 municipalities with a first term mayor. Column 2 reports the mean for the 213 municipalities with second-term mayors. Column 3 reports the difference in means and robust standard error of the difference are presented in brackets. 
Table 3: Summary Statistics of Mayors and Municipalities

\begin{tabular}{|c|c|c|c|}
\hline & $\begin{array}{c}\begin{array}{c}\text { First-term } \\
\text { mayors }\end{array} \\
\end{array}$ & $\begin{array}{c}\begin{array}{c}\text { Second-term } \\
\text { mayors }\end{array} \\
\end{array}$ & Difference \\
\hline \multicolumn{4}{|l|}{ Mayor characteristics: } \\
\hline Male & 0.95 & 0.96 & $\begin{array}{c}-0.01 \\
{[0.020]}\end{array}$ \\
\hline Schooling & 6.10 & 6.07 & $\begin{array}{c}0.03 \\
{[0.176]}\end{array}$ \\
\hline Age & 47.86 & 46.67 & $\begin{array}{c}1.19 \\
{[0.848]}\end{array}$ \\
\hline \multicolumn{4}{|l|}{ Municipal Characteristics } \\
\hline Population & 25828.74 & 24878.19 & $\begin{array}{c}950.54 \\
{[3877.32]}\end{array}$ \\
\hline$\%$ urban population & 0.62 & 0.58 & $\begin{array}{c}0.046 \\
{[0.021]^{* *}}\end{array}$ \\
\hline$\%$ adults with secondary school & 0.25 & 0.22 & $\begin{array}{c}0.028 \\
{[0.010]^{* * *}}\end{array}$ \\
\hline New municipality & 0.21 & 0.27 & $\begin{array}{c}-0.055 \\
{[0.039]}\end{array}$ \\
\hline GDP per capita (R\$ 1000) & 5309.95 & 6189.44 & $\begin{array}{c}-879.490 \\
{[1226.10]}\end{array}$ \\
\hline Gini coefficient & 0.57 & 0.57 & $\begin{array}{c}0.007 \\
{[0.005]}\end{array}$ \\
\hline Intergovernmental transfers ( $\mathrm{R} \$$ million) & 12.50 & 11.90 & $\begin{array}{c}0.56 \\
{[1.943]}\end{array}$ \\
\hline Participatory budgeting & 0.03 & 0.03 & $\begin{array}{c}0.008 \\
{[0.028]}\end{array}$ \\
\hline \multicolumn{4}{|l|}{ Political Characteristics } \\
\hline \% legislators in mayor's party & 0.27 & 0.36 & $\begin{array}{c}-0.087 \\
{[0.014]^{* * *}}\end{array}$ \\
\hline Legislators per voter $(\times 100)$ & 0.14 & 0.15 & $\begin{array}{c}-0.01 \\
{[0.01]}\end{array}$ \\
\hline Effective number parties legislature & 4.55 & 3.91 & $\begin{array}{c}0.643 \\
{[0.145]^{* * *}}\end{array}$ \\
\hline Margin of victory in 2000 elections & 0.15 & 0.23 & $\begin{array}{c}-0.083 \\
{[0.018]^{* * *}}\end{array}$ \\
\hline Judiciary district & 0.57 & 0.52 & $\begin{array}{c}0.046 \\
{[0.046]}\end{array}$ \\
\hline Media & 0.79 & 0.77 & $\begin{array}{c}0.018 \\
{[0.038]}\end{array}$ \\
\hline Number of audited items & 41.50 & 42.72 & $\begin{array}{c}-1.221 \\
{[1.894]}\end{array}$ \\
\hline Total Resources Audited (R\$ million) & 5.86 & 5.18 & $\begin{array}{c}0.68 \\
{[0.75]}\end{array}$ \\
\hline
\end{tabular}

Notes: This table presents a comparison of the mean political, mayor, and socio-economic characteristics of the municipalities between first and second-term mayors. These statistics were only computed for the 476 municipalities that contained the full set of non-missing characteristics. Column 1 reports the means for the 270 municipalities with a first term mayor. Column 2 reports the mean for the 206 municipalities with second-term mayors. Column 3 reports the difference in means and robust standard error of the difference are presented in brackets significantly different than zero at $99(* * *), 95(* *), 90(*)$ percent confidence. 
Table 4: The Effects of Re-election Incentives on Corruption

\begin{tabular}{|c|c|c|c|c|c|c|c|c|}
\hline \multirow[t]{3}{*}{ Dependent variable: } & \multicolumn{8}{|c|}{$\underline{\text { Share of audited resources related to corruption }}$} \\
\hline & \multicolumn{6}{|c|}{ OLS } & \multirow{2}{*}{$\frac{\text { Matching }}{(7)}$} & \multirow{2}{*}{$\frac{\text { Tobit }}{(8)}$} \\
\hline & $(1)$ & $(2)$ & $(3)$ & $(4)$ & $(5)$ & $(6)$ & & \\
\hline Mayor in first-term & $\begin{array}{c}-0.019 \\
{[0.009]^{* *}}\end{array}$ & $\begin{array}{c}-0.020 \\
{[0.010]^{* *}}\end{array}$ & $\begin{array}{c}-0.020 \\
{[0.010]^{* *}}\end{array}$ & $\begin{array}{c}-0.024 \\
{[0.011]^{* *}}\end{array}$ & $\begin{array}{c}-0.026 \\
{[0.011]^{* *}}\end{array}$ & $\begin{array}{c}-0.027 \\
{[0.011]^{* *}}\end{array}$ & $\begin{array}{c}-0.028 \\
{[0.010]^{* *}}\end{array}$ & $\begin{array}{c}-0.042 \\
{[0.012]^{* *}}\end{array}$ \\
\hline R-squared & 0.01 & 0.08 & 0.10 & 0.12 & 0.14 & 0.20 & & 0.20 \\
\hline Mayor characteristics & No & Yes & Yes & Yes & Yes & Yes & Yes & Yes \\
\hline Municipal characteristics & No & No & Yes & Yes & Yes & Yes & Yes & Yes \\
\hline Political and judicial institutior & No & No & No & Yes & Yes & Yes & Yes & Yes \\
\hline Lottery intercepts & No & No & No & No & Yes & Yes & Yes & Yes \\
\hline State intercepts & No & No & No & No & No & Yes & Yes & Yes \\
\hline
\end{tabular}

Notes: This table reports the effects of re-election incentives on share of resources found to corrupt. Columns 1-6 present the results of an OLS regression of the dependent variables listed in that column on an indicator variable for whether the mayor is in his first term. Column 7 estimates the relationship using Abadie and Imbens (2004) matching estimator and Column 8 use a Tobit specification. Mayor characteristics include the age, gender, education and party affiliation of the mayor. Municipal characteristics: population expressed in logarithms, percentage of the population that has at least a secondary education, percentage of the population that lives in the urban sector, new municipality, log GDP per capita per in 2002, Gini coefficient. Political and judicial institutions include: effective number of political parties in the legislature, the number of legislator per voter, the share of the legislature that is of the same party as the mayor, and whether the municipality is judiciary district, and the amount of resources sent to the municipal expressed in logarithms. Robust standard errors are displayed in brackets. Significantly different than zero at $99(* * *), 95(* *)$, $90\left(^{*}\right)$ percent confidence. 
Table 5: The Effects of Re-election Incentives on Alternative Measures of Corruption

\begin{tabular}{|c|c|c|c|c|c|c|c|c|}
\hline \multirow[t]{3}{*}{ Dependent variables: } & \multicolumn{4}{|c|}{ Numbers of irregularities related to corruption } & \multicolumn{4}{|c|}{ S $\underline{\text { Share of audited items related to corruption }}$} \\
\hline & \multicolumn{2}{|c|}{ OLS } & \multirow{2}{*}{$\frac{\text { Matching }}{\text { (3) }}$} & \multirow{2}{*}{$\frac{\text { Poisson }}{(4)}$} & \multicolumn{2}{|c|}{ OLS } & \multirow{2}{*}{$\begin{array}{c}\text { Matching } \\
(7)\end{array}$} & \multirow{2}{*}{$\frac{\text { Tobit }}{(8)}$} \\
\hline & $(1)$ & $(2)$ & & & (5) & (6) & & \\
\hline Mayor in first-term & $\begin{array}{c}-0.388 \\
{[0.158]^{* *}}\end{array}$ & $\begin{array}{c}-0.467 \\
{[0.148]^{* * *}}\end{array}$ & $\begin{array}{c}-0.339 \\
{[0.146]^{* *}}\end{array}$ & $\begin{array}{c}-0.500 \\
{[0.127]^{* *}}\end{array}$ & $\begin{array}{c}-0.008 \\
{[0.005]}\end{array}$ & $\begin{array}{c}-0.010 \\
{[0.004]^{* *}}\end{array}$ & $\begin{array}{c}-0.010 \\
{[0.005]^{*}}\end{array}$ & $\begin{array}{c}-0.009 \\
{[0.005]^{*}}\end{array}$ \\
\hline R-squared & 0.01 & 0.43 & & 0.17 & 0.01 & 0.45 & & -0.44 \\
\hline Mayor characteristics & No & Yes & Yes & Yes & No & Yes & Yes & Yes \\
\hline Municipal characteristics & No & Yes & Yes & Yes & No & Yes & Yes & Yes \\
\hline Political and judicial institution & No & Yes & Yes & Yes & No & Yes & Yes & Yes \\
\hline Lottery intercepts & No & Yes & Yes & Yes & No & Yes & Yes & Yes \\
\hline State intercepts & No & Yes & Yes & Yes & No & Yes & Yes & Yes \\
\hline
\end{tabular}

Notes: This table reports the effects of re-election incentives on number of irregularities associated with corruption and the share of service items found to corrupt. Columns 1 -2 and columns 5-6 present the results of an OLS regression of the dependent variables listed in that column on an indicator variable for whether the mayor is in his first term. Columns 3 and 7 estimate the relationship using Abadie and Imbens (2004) matching estimator; Column 4 uses a Poisson specification and Column 8 uses a Tobit specification. Mayor characteristics include the age, gender, education and party affiliation of the mayor. Municipal characteristics: population expressed in logarithms, percentage of the population that has at least a secondary education, percentage of the population that lives in the urban sector, new municipality, log GDP per capita per in 2002, Gini coefficient. Political and judicial institutions include: effective number of political parties in the legislature, the number of legislator per voter, the share of the legislature that is of the same party as the mayor, and whether the municipality is judiciary district, and the amount of resources sent to the municipal expressed in logarithms. Robust standard errors are displayed in brackets. Significantly different than zero at $99(* * *), 95(* *), 90\left(^{*}\right)$ percent confidence. 
Table 6: The Effect of Re-Election Incentives on Corruption Controlling for Ability

\begin{tabular}{|c|c|c|c|c|c|}
\hline \multirow[t]{2}{*}{ Dependent variable: } & \multicolumn{5}{|c|}{ Share of audited resources related to corruption } \\
\hline & RDD linear & RDD quadratic & RDD cubic & $\begin{array}{l}\text { Second-term and } \\
\text { first-term later } \\
\text { re-elected }\end{array}$ & $\begin{array}{c}\text { Second-term and first- } \\
\text { term later re-elected } \\
\text { predicted }\end{array}$ \\
\hline \multirow{3}{*}{ Mayor in first-term } & $(1)$ & $(2)$ & (3) & (4) & (5) \\
\hline & -0.029 & -0.032 & -0.037 & -0.040 & -0.034 \\
\hline & {$[0.017]^{*}$} & {$[0.018]^{*}$} & {$[0.020]^{*}$} & {$[0.013]^{* * *}$} & {$[0.0177]^{*}$} \\
\hline Observations & 328 & 328 & 328 & 313 & 313 \\
\hline R-squared & 0.17 & 0.17 & 0.17 & 0.27 & 0.29 \\
\hline Mayor characteristics & Yes & Yes & Yes & Yes & Yes \\
\hline Municipal characteristics & Yes & Yes & Yes & Yes & Yes \\
\hline Political and judicial institutions & Yes & Yes & Yes & Yes & Yes \\
\hline Lottery intercepts & Yes & Yes & Yes & Yes & Yes \\
\hline
\end{tabular}

Notes: This table reports the effects of re-election incentives on the share of resources found to corrupt. Columns 1 - 3 include only municipalities where the incumbent ran for reelection. Column 4-5 includes second-term mayors and first-mayors that get re-elected in the subsequent election. Column 5 includes second-term mayors and first-term mayor predicted to be re-elected in the 2004 elections. Mayor characteristics include the age, gender, education and party affiliation of the mayor. Municipal characteristics: population expressed in logarithms, percentage of the population that has at least a secondary education, percentage of the population that lives in the urban sector, new municipality, log GDP per capita per in 2002, Gini coefficient. Political and judicial institutions include: effective number of political parties in the legislature, the number of legislator per voter, the share of the legislature that is of the same party as the mayor, and whether the municipality is judiciary district, and the amount of resources sent to the municipal expressed in logarithms. Robust standard errors are displayed in brackets. Significantly different than zero at $99(* * *), 95(* *), 90(*)$ percent confidence. 
Table 7: The Effect of Re-Election Incentives on Corruption Controlling for Experience and Career Concerns

\begin{tabular}{|c|c|c|c|c|c|}
\hline \multirow[t]{3}{*}{ Dependent variable: } & \multicolumn{5}{|c|}{$\underline{\underline{\text { Share of audited resources related to corruption }}}$} \\
\hline & Full sample & $\begin{array}{c}\text { Second-term and } \\
\text { first-term that } \\
\text { served as previous } \\
\text { mayors }\end{array}$ & $\begin{array}{l}\text { Second-term and } \\
\text { first-term that } \\
\text { served as mayor or } \\
\text { legislator in past }\end{array}$ & $\begin{array}{l}\text { Second-term and first-term } \\
\text { that served as mayor or } \\
\text { legislator in past and were } \\
\text { later reelected }\end{array}$ & $\begin{array}{l}\text { Second- } \\
\text { terms only }\end{array}$ \\
\hline & (1) & $(2)$ & (3) & (4) & (5) \\
\hline Mayor in first-term & $\begin{array}{c}-0.031 \\
{[0.012]^{* *}}\end{array}$ & $\begin{array}{c}-0.039 \\
{[0.014]^{* * *}}\end{array}$ & $\begin{array}{c}-0.029 \\
{[0.016]^{*}}\end{array}$ & $\begin{array}{c}-0.056 \\
{[0.018]^{* * *}}\end{array}$ & \\
\hline Mayor with political experience & $\begin{array}{c}0.005 \\
{[0.013]}\end{array}$ & & & & \\
\hline Future candidate for higher level offices & & & & & $\begin{array}{c}-0.049 \\
{[0.021]^{* *}}\end{array}$ \\
\hline$\overline{\text { R-squared }}$ & 0.21 & 0.31 & 0.29 & 0.33 & 0.33 \\
\hline Observations & 467 & 280 & 304 & 240 & 200 \\
\hline Mayor and municipal characteristics & Yes & Yes & Yes & Yes & Yes \\
\hline Political and judiciary institutions & Yes & Yes & Yes & Yes & Yes \\
\hline Lottery intercepts & Yes & Yes & Yes & Yes & Yes \\
\hline State intercepts & Yes & Yes & Yes & Yes & Yes \\
\hline
\end{tabular}

Notes: This table reports the effects of re-election incentives on the share of resources found to corrupt. Column 1 uses the full sample. Column 2 includes only municipalities with a second-term mayor and first-term mayor who had been mayor in a previous term. Column 3 includes only municipalities with a second-term mayor and first-term mayors who had been either a mayor or legislator in a previous term. Column 4 includes second-term mayors and first-mayors that get re-elected in the subsequent election and served as either a mayor or legislator in the past. Column 5 includes only second-term mayors. Mayor characteristics include the age, gender, education and party affiliation of the mayor. Municipal characteristics: population expressed in logarithms, percentage of the population that has at least a secondary education, percentage of the population that lives in the urban sector, new municipality, log GDP per capita per in 2002, Gini coefficient. Political and judicial institutions include: effective number of political parties in the legislature, the number of legislator per voter, the share of the legislature that is of the same party as the mayor, and whether the municipality is judiciary district, and the amount of resources sent to the municipal expressed in logarithms. Robust standard errors are displayed in brackets. Significantly different than zero at 99 (***), 95 (**), $90(*)$ percent confidence. 
Table 8: Local Characteristics and the Effect of Re-Election Incentives on Corruption

\begin{tabular}{|c|c|c|c|c|}
\hline \multirow[t]{2}{*}{ Dependent variable: } & \multicolumn{4}{|c|}{ Share of audited resources related to corruption } \\
\hline & (1) & (2) & (3) & (4) \\
\hline Mayor in first-term & -0.049 & -0.098 & -0.066 & -0.045 \\
\hline & {$[0.017]^{* * *}$} & {$[0.029]^{* * *}$} & {$[0.025]^{* * *}$} & {$[0.022]^{* * *}$} \\
\hline Judiciary district & $\begin{array}{c}-0.029 \\
{[0.018]}\end{array}$ & & & \\
\hline First-term $\times$ Judiciary district & $\begin{array}{c}0.037 \\
{[0.020] *}\end{array}$ & & & \\
\hline Media & & $\begin{array}{c}-0.051 \\
{[0.026]^{* *}}\end{array}$ & & \\
\hline First-term $\times$ Media & & $\begin{array}{c}0.084 \\
{[0.029]^{* *}}\end{array}$ & & \\
\hline Legislative support & & & $\begin{array}{c}-0.138 \\
{[0.053]^{* * *}}\end{array}$ & \\
\hline First-term $\times$ Legislative support & & & $\begin{array}{c}0.120 \\
{[0.060]^{* *}}\end{array}$ & \\
\hline Political competition & & & & $\begin{array}{c}-0.149 \\
{[0.097]}\end{array}$ \\
\hline First-term $\times$ Political competition & & & & $\begin{array}{c}0.071 \\
{[0.078]}\end{array}$ \\
\hline F-test joint hypothesis & 4.05 & 5.87 & 3.83 & 3.33 \\
\hline P-value & 0.02 & 0.00 & 0.02 & 0.04 \\
\hline R-squared & 0.21 & 0.23 & 0.21 & 0.21 \\
\hline
\end{tabular}

Notes: This table reports the effects of re-election incentives on share of resources found to corrupt. The sample includes all 476 municipalities. All regressions include mayor characteristics, municipal characteristics, political and judiciary characteristics, state and lottery intercepts. Political competition is defined as 1 divided by the effective number of political parties. Mayor characteristics include the age, gender, education and party affiliation of the mayor. Municipal characteristics: population expressed in logarithms, percentage of the population that has at least a secondary education, percentage of the population that lives in the urban sector, new municipality, log GDP per capita per in 2002, Gini coefficient. Political and judicial institutions include: effective number of political parties in the legislature, the number of legislator per voter, the share of the legislature that is of the same party as the mayor, and whether the municipality is judiciary district, and the amount of resources sent to the municipal expressed in logarithms. Robust standard errors are displayed in brackets. Significantly different than zero at $99(* * *), 95(* *), 90(*)$ percent confidence. 
Table 9: Testing for the Political Manipulation of Audit Reports

\begin{tabular}{|c|c|c|c|c|c|}
\hline \multirow[t]{2}{*}{ Dependent variable: } & \multicolumn{3}{|c|}{$\begin{array}{c}\text { Share of audited resources } \\
\text { indicated as corruption }\end{array}$} & \multicolumn{2}{|c|}{$\begin{array}{c}\text { Log(value projects } \\
\text { audited) }\end{array}$} \\
\hline & (1) & $(2)$ & (3) & (3) & (4) \\
\hline Mayor in first-term & $\begin{array}{c}-0.025 \\
{[0.014]^{*}}\end{array}$ & $\begin{array}{c}-0.028 \\
{[0.011]^{* *}}\end{array}$ & $\begin{array}{c}-0.03 \\
{[0.013]^{* *}}\end{array}$ & $\begin{array}{c}0.05 \\
{[0.124]}\end{array}$ & $\begin{array}{r}0.084 \\
{[0.169]}\end{array}$ \\
\hline Audited in election year & $\begin{array}{c}-0.006 \\
{[0.014]}\end{array}$ & & & & $\begin{array}{r}0.082 \\
{[0.136]}\end{array}$ \\
\hline First-term $\times$ audited in election year & $\begin{array}{c}0.001 \\
{[0.017]}\end{array}$ & & & & $\begin{array}{l}-0.087 \\
{[0.172}\end{array}$ \\
\hline Mayor in PT & & $\begin{array}{l}-0.045 \\
{[0.047]}\end{array}$ & & & \\
\hline First-term $\times$ mayor in PT & & $\begin{array}{c}0.023 \\
{[0.050]}\end{array}$ & & & \\
\hline Mayor same party governor & & & $\begin{array}{c}-0.01 \\
{[0.017]}\end{array}$ & & \\
\hline First-term $\times$ same party governor & & & $\begin{array}{c}0.012 \\
{[0.020]}\end{array}$ & & \\
\hline R-squared & 0.18 & 0.21 & 0.21 & 0.59 & 0.59 \\
\hline
\end{tabular}

Notes: This table reports the effects of re-election incentives on share of resources found to corrupt. Columns 1-4 present the results of an OLS regression of the dependent variables listed in that column on an indicator variable for whether the mayor is in his first term in addition to the other variables listed. The sample includes all 476 municipalities. All regressions include mayor characteristics, municipal characteristics, political and judiciary characteristics, state and lottery intercepts. Mayor characteristics include the age, gender, education and party affiliation of the mayor. Municipal characteristics: population expressed in logarithms, percentage of the population that has at least a secondary education, percentage of the population that lives in the urban sector, new municipality, log GDP per capita per in 2002, Gini coefficient. Political and judicial institutions include: effective number of political parties in the legislature, the number of legislator per voter, the share of the legislature that is of the same party as the mayor, and whether the municipality is judiciary district, and the amount of resources sent to the municipal expressed in logarithms. Robust standard errors are displayed in brackets. Significantly different than zero at $99\left({ }^{* * *}\right), 95(* *), 90(*)$ percent confidence. 
Appendix Table 1: The Effect of Re-Election Incentives on Corruption Controlling for Ability: Alternative Functional Forms

\begin{tabular}{|c|c|c|c|c|}
\hline & $\begin{array}{l}\text { Incumbents who run } \\
\text { for reelection in } 2000\end{array}$ & $\begin{array}{l}\text { RDD linear } \\
\text { spline }\end{array}$ & $\begin{array}{l}\text { RDD quadratic } \\
\text { spline }\end{array}$ & $\begin{array}{c}\text { RDD cubic } \\
\text { spline }\end{array}$ \\
\hline & (1) & (3) & (4) & (5) \\
\hline \multirow[t]{2}{*}{ Mayor in first-term } & -0.020 & -0.032 & -0.043 & -0.020 \\
\hline & {$[0.011]^{*}$} & {$[0.017]^{*}$} & {$[0.023]^{*}$} & {$[0.027]$} \\
\hline Win margin & & $\begin{array}{c}-0.016 \\
{[0.041]}\end{array}$ & $\begin{array}{c}-0.034 \\
{[0.111]}\end{array}$ & $\begin{array}{c}0.085 \\
{[0.221]}\end{array}$ \\
\hline Win Margin $^{2}$ & & & $\begin{array}{c}0.026 \\
{[0.144]}\end{array}$ & $\begin{array}{c}-0.413 \\
{[0.669]}\end{array}$ \\
\hline Win Margin $^{3}$ & & & & $\begin{array}{c}0.391 \\
{[0.540]}\end{array}$ \\
\hline First-term $\times$ Win Margin & & $\begin{array}{c}-0.050 \\
{[0.087]}\end{array}$ & $\begin{array}{c}-0.184 \\
{[0.219]}\end{array}$ & $\begin{array}{c}0.135 \\
{[0.423]}\end{array}$ \\
\hline First-term $\times$ Win Margin ${ }^{2}$ & & & $\begin{array}{c}-0.362 \\
{[0.377]}\end{array}$ & $\begin{array}{c}2.196 \\
{[1.590]}\end{array}$ \\
\hline First-term $\times$ Win Margin ${ }^{3}$ & & & & $\begin{array}{c}2.084 \\
{[1.617]}\end{array}$ \\
\hline Observations & 328 & 328 & 328 & 328 \\
\hline R-squared & 0.17 & 0.17 & 0.17 & 0.18 \\
\hline Mayor characteristics & Yes & Yes & Yes & Yes \\
\hline Municipal characteristics & Yes & Yes & Yes & Yes \\
\hline Political and judicial institu & Yes & Yes & Yes & Yes \\
\hline Lottery intercepts & Yes & Yes & Yes & Yes \\
\hline
\end{tabular}

Notes: This table reports the effects of re-election incentives on share of resources found to corrupt. The sample includes all 328 municipalities, where the incumbent ran for reelection. Mayor characteristics include the age, gender, education and party affiliation of the mayor. Municipal characteristics: population expressed in logarithms, percentage of the population that has at least a secondary education, percentage of the population that lives in the urban sector, new municipality, log GDP per capita per in 2002, Gini coefficient. Political and judicial institutions include: effective number of political parties in the legislature, the number of legislator per voter, the share of the legislature that is of the same party as the mayor, and whether the municipality is judiciary district, and the amount of resources sent to the municipal expressed in logarithms. Robust standard errors are displayed in brackets. Significantly different than zero at $99(* * *), 95(* *), 90(*)$ percent confidence. 